\title{
Determining the Relation between Nursing Students' Problem-Solving Skills and Attitudes toward Computer Use in Health Care: A Comparative Study
}

\author{
Mine Seçir ${ }^{1}$ (D) , Arzu Karabağ Aydın²
}

${ }^{1}$ Manyas State Hospital, Medical Department, 10470 Balıkesir, Turkey

${ }^{2}$ Kafkas University, Faculty of Health Sciences Department of Nursing, 36100 Kars, Turkey

Mine SEÇîR

Arzu KARABAĞ AYDIN

This study was orally presented at the $2^{\text {nd }}$ Palandöken International Nursing Education Congress in Turkey

This study was prepared from Mine Seçir' master thesis under the supervision of Assistant Professor Arzu Karabağ Aydın

Correspondence: Arzu Karabağ Aydın Kafkas University, Faculty of Health Sciences Department of Nursing, 36100 Kars, Turkey Phone: +905555531543

E-mail: akarabag.aydin@gmail.com

$\begin{array}{ll}\text { Received } & : 5 \text { April } 2021 \\ \text { Accepted } & : 3 \text { August } 2021\end{array}$

\section{ABSTRACT}

Aim: This study aimed to determine the relation between nursing students' problem-solving skills and attitudes toward computer use in health care.

Methods: This was a cross-sectional and correlational study conducted between December 3 and 7, 2018 in the nursing department of the faculty of health sciences of a university in the northeastern region of Turkey. The study sample comprised 587 (73\%) of nursing students. Data were collected using a descriptive characteristics form, the ProblemSolving Inventory and the Pretest for Attitudes Toward Computers in Healthcare scale. Scale total scores and subscale and subgroup mean scores were calculated. Descriptive statistics were presented as numbers and percentages. Data were analyzed using the Mann-Whitney U, Kruskal-Wallis H, and Spearman correlation tests.

Results: The mean age of participants was $20.66 \pm 1.79$ years. Of the participants, $61.0 \%$ were women. They had mean scores of $93.41 \pm 18.73$ and $8.36 \pm 9.58$ on the Problem-Solving Inventory and the Pretest for Attitudes Toward Computers in Healthcare scale, respectively. The Problem-Solving Inventory was weakly and negatively related with the Pretest for Attitudes Toward Computers in Healthcare scale $(p=0.000, r=-0.363)$.

Conclusion:This study found that nursing students who had low scores on the Problem-Solving Inventory, that is, stronger problem-solving skills, demonstrated more positive attitudes toward computer use in health care. Based on these results, the following recommendations were made. Students' problem-solving skills should be evaluated at the beginning of each academic year. During clinical internships, mentor nurses should introduce students to nursing informatics.

Keywords: Attitude, computers, health care, nursing students, problem solving

Hemşirelik Öğrencilerinin Problem Çözme Becerileri ile Sağlık Bakımında Bilgisayar Kullanımına Yönelik Tutumları Arasındaki illişkinin Belirlenmesi: Karşılaştırmalı Bir Çalışma

ÖZET

Amaç: Bu çalışma, hemşirelik öğrencilerinin problem çözme becerileri ile sağlık hizmetlerinde bilgisayar kullanımına yönelik tutumları arasındaki ilişkiyi belirlemek amacıyla yapıııııștır.

Yöntemler:. Bu çalışma, Türkiye'nin kuzeydoğu bölgesindeki bir üniversitenin sağlık bilimleri fakültesi hemşirelik bölümünde 3-7 Aralık 2018 tarihleri arasında gerçekleștirilmiş, kesitsel ve ilişki arayıı bir çalıșmadır. Araștırmanın örneklemini, hemşirelik bölümünde öğrenim gören 587 öğrenci (\% 73) oluşturmuștur. Veriler, tanımlayııı özellikler formu, Problem Çözme Envanteri ve Sağlık Bakımında Bilgisayar Kullanımına Yönelik Tutum Ölçeği kullanılarak toplanmıştır. Ölçek toplam puanları ile alt ölçek ve alt grup ortalamaları hesaplanmışıı. Tanımlayıcı istatistikler sayı ve yüzde olarak sunulmuştur. Veriler, Mann - Whitney U, Kruskal - Wallis H ve Spearman korelasyon testleri kullanılarak analiz edilmiştir.

Bulgular: Katılımcıların yaş ortalamasının 20.66 1.79 yıl olduğu, \% 61.0'inin kadın olduğu bulunmuştur. Sağlık Bakımında Bilgisayar Kullanımına Yönelik Tutum Ölçeği toplam puan ortalaması 8.36 \pm 9.58 , Problem Çözme Envanteri toplam puan ortalaması ise $93.41 \pm 18.73$ 'dir. Problem Cözme Envanteri ile Sağlık Bakımında Bilgisayar Kullanımına Yönelik Tutum Ölçeği arasında negatif yönlü, zayıf anlamlı ilişki olduğu belirlenmiştir $(p=0.000, r=-0.363)$.

Sonuç: Bu çalışmada, Problem Çözme Envanterinden düşük puan alan, yani daha güçlü problem çözme becerisine sahip hemşirelik öğrencilerinin sağlık bakımında bilgisayar kullanımına yönelik daha olumlu tutum sergiledikleri bulunmuştur.

Anahtar Sözcükler: Bilgisayar, hemşirelik öğrencileri, problem çözme, sağlık bakımı, tutum 
$\mathbf{N}$ urses provide services in fast-paced environments where change is continuous and fast (1), making them use creative, analytical, critical thinking, and decision making skills to manage complex, unique, and high-risk patient care $(1,2)$. Problem-solving skills in nursing are professional skills that call for effective and rapid clinical decisions that play a key role in providing safe, high-quality, and personalized care (3).

Nursing students providing care in the future in collaboration with other healthcare professionals should practice in realistic and safe clinical settings in order to better their skills (4). Nursing students use problem-solving skills more actively when witnessing loss and death in clinical settings and negative emotions of patients suffering and experiencing hopelessness (5). Helping nursing students develop problem-solving skills is one of the main objectives of the core courses of nursing education (6). Therefore, nursing curricula should be designed in such a way to provide nursing students with the opportunity to develop problem-solving skills $(2,6)$. Researches shows that problem-solving skills in nursing students can be developed through training and activities $(7,8)$ and are correlated with readiness for self-learning, academic self-efficacy (9), social anxiety (6), lifelong learning trends (10), and critical thinking (2), and are affected by some independent variables (gender, family type, school graduated) (11).

Problem-solving skills not only help university students solve problems but also make them more capable of accessing information (12). However, the use of computers, which is one of the means of accessing information in nursing practices, has become more and more widespread day by day and has become a mandatory component of health care due to the benefits it provides (13). Academics should, therefore, keep up with advances in technology in order to train nursing students properly (14). It is recommended that undergraduate pre-internship nursing courses involve simulation, video games, learning labs (15), and 3-D, telehealth, and e-learning (16) in order to prepare nursing students for real clinical settings and to bridge the gap between theory and practice (17).

Various studies also show that nursing students had positive attitudes toward computer use in health care (18), affected by having received basic computer education (19) and associated with clinical decision-making skills (20).

To our knowledge, there is no research investigating the relation between nursing students' problem-solving skills and attitudes toward computer use in health care.. In addition to this, it is believed that the results obtained from this study can help be a guide in the training of nurses in regards to critical thinking and clinical decision-making skills, utilizing appropriate technologies in patient care, providing quality patient care, and working as a professional member of the nursing profession.

This study search answers to the following questions: What are the problem solving skills of nursing students? What factors affect nursing students' problem-solving skills? What are the nursing students' attitudes towards computer use in health care? What factors affect nursing students' attitudes toward computer use in health care? Is there a relation between nursing students' problem-solving skills and their attitudes toward computer use in health care?

\section{Method}

Objective

This study aimed to determine the relation between nursing students' problem-solving skills and their attitudes toward computer use in health care.

Design

This was a cross-sectional and correlational study.

\section{Setting/Sampling}

The study was conducted during the 2018-2019 fall semester in the nursing department of the faculty of health sciences at a university in the TRA2 northeastern region of Turkey (TRA2: Ağrı, Kars, Ardahan, lğdır). The study population comprised 804 nursing students (198 first-year, 209 second-year, 159 third-year, and 238 fourth-year students). No sampling was performed. Those who agreed to participate in the study were included in the sample. The initial study sample consisted of 591 students. However, four nurses were excluded because they failed to complete the data collection. Therefore, the final study sample consisted of 587 students $(73 \%$ of the total study population).

\section{Data Collection Tools}

Data were collected using a descriptive characteristics form, the Problem-Solving Inventory (PSI) and the Pretest for Attitudes Toward Computers in Healthcare (PATCH) assessment scale.

\section{Descriptive characteristics form}

The descriptive characteristics form is based on the literature $(10,20)$, with a total of 20 questions prepared by 
the researchers (students' year of study, age, gender, most recently completed education program, perceived obstacles in the learning process, reasons for choosing the profession, owning a personal computer, etc.).

\section{Problem-Solving Inventory (PSI)}

The PSI was developed by Heppner and Peterson (1982) to measure perceived problem-solving skills. Şahin, Şahin, and Heppner (21) adapted it to Turkish and established its validity and reliability. The PSI consists of thirtyfive items and six subscales: "Hasty Approach" (9 items), "Thinking Approach" (5 items), "Avoidant Approach" (4 items), "Evaluative Approach" (3 items), "Self-Confident Approach" (6 items), and "Planned Approach" (4 items). The inventory uses a six-point Likert-type scale $(1=$ "I always act like this"; $2=$ "I mostly act like this"; $3=$ "I often act like this"; $4=$ "I act like this occasionally"; $5=$ "I rarely act like this"; $6=$ "I never act like this"). Items 9, 11, 22 and 29 are not scored. Items 1-4, 13-15, 17, 21, 25, 26, 30, and 34 are reverse-scored. The lowest and the highest possible points that can be obtained from the scale are 31 and 186, respectively. $A$ high score indicates that the perceived problem-solving skill is low, while a low score indicates that the perceived problem-solving skill is high (21). The PSI had a Cronbach's alpha of 0.88 in the study of Şahin, Şahin, and Heppner (21). The PSI had a Cronbach's alpha of 0.84 in this study.

\section{Pretest for Attitudes Toward Computers in Healthcare (PATCH)}

The PATCH scale was developed by Kaminski (1996) to evaluate students' attitudes toward computer use. Kaya and Atabek Aşti (22) adapted it to Turkish and established its validity and reliability. It consists of forty items. Items $1,2,4,6-8,11,12,16-19,21,24,29,31,33,34,36$, and 37 are positive statements scored on a five-point Likert-type scale (strongly agree $=1$; agree $=0.5$; neither agree nor disagree $=0$; disagree $=-0.5$; strongly disagree $=-1$ ). Items $3,5,9,10,13-15,20,22,23,25-28,30,32,35$, and $38-40$ are negative statements reverse-scored (strongly agree $=$ -1 ; agree $=-0.5$; neither agree nor disagree $=0$; disagree $=0.5$; strongly disagree $=1$ ). The total score ranges from -40 to +40 . The scale evaluates attitudes toward computer use in health care in six different score groups: group 1 between -40 and -28 ; group 2 = between -27 and -15 ; group $3=$ between -14 and -4 ; group $4=$ between -3 and 12 ; group $5=$ between 13 and 26 ; and group $6=$ between 27 and 40 . Higher scores indicate more positive attitudes toward computer use in health care (22). The PATCH had a Cronbach's alpha of 0.92 in the study of Kaya and Atabek Aști (22). The PATCH had a Cronbach's alpha of 0.88 in this study.

\section{Data Collection}

A pilot test was conducted on February 16, 2018 to test the intelligibility of the descriptive characteristics form. The pilot test sample consisted of 14 volunteer students of the midwifery department of the same faculty. The volunteer midwifery students had similar characteristics to the main study sample. The form was revised based on the pilot study. After distributing the survey, the starting and ending times were recorded, and the average completion time was determined to be 15-20 minutes.

The main study was conducted between December 3 and 7,2018 . The weekly course schedule of the nursing department was checked to determine the suitable course in which to conduct the study, and permission was obtained prior from the instructor of the related course.

\section{Ethical Considerations}

The study was approved by the Ethics Committee of the Faculty of Medicine of University (No: 80576354-05099/180, Date: December 13, 2017). Written permission was obtained from the authors who conducted the Turkish validity and reliability study of the PSI and PATCH scales used in the study. In order to conduct the research, written permission from the faculty of health sciences and consent of all students who voluntarily accepted to participate in the research were obtained.

\section{Data Analysis}

The gathered data were analyzed using the IBM Statistical Package for Social Sciences (SPSS) for Windows Version 20.0. Frequencies and percentages were calculated for demographic characteristics.

Participants' mean PSI and PATCH scores and subscale and subgroup scores were calculated. The KolmogorovSmirnov (KS) test was used to determine whether the data met the assumptions for parametric tests. The KruskalWallis $\mathrm{H}(\mathrm{KW})$ and Mann-Whitney $\mathrm{U}(\mathrm{Z})$ tests were used for non-normally distributed data. Spearman's correlation was used to determine the correlation between the PSI and PATCH scores. For the significance level of statistical tests, $\mathrm{p}<0.05$ value is accepted. 


\section{Results}

Table 1 shows the distribution of participants' PSI and PATCH scores based on descriptive characteristics. Of the participants, $30.0 \%, 26.0 \%, 21.5 \%$, and $22.5 \%$ were first-, second-, third-, and fourth-year students, respectively. Of them, $61.0 \%$ were women, $59.5 \%$ held degrees from Anatolian high schools, and $3.9 \%$ completed health science vocational high schools. In the study, the mean age of nursing students was determined to be $20.66 \pm 1.79$.
Table 2 shows the participants' mean PSI scale and subscale scores. They had a mean PSI score of $93.41 \pm 18.73$. The mean PSI subscale scores were as follows: "Hasty Approach" - 30.74 \pm 7.04 ; "Self-Confident Approach" 17.23 \pm 5.50 ; "Thinking Approach" - 14.08 4 4.63; "Avoidant

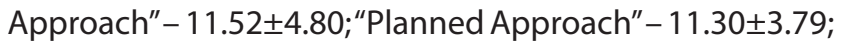
and "Evaluative Approach" - 8.52 \pm 3.25 .

\begin{tabular}{|c|c|c|c|c|c|}
\hline \multirow{2}{*}{$\begin{array}{c}\text { Descriptive } \\
\text { Characteristics }\end{array}$} & \multirow{2}{*}{ n (\%) } & \multicolumn{2}{|c|}{ PSI } & \multicolumn{2}{|c|}{ PATCH } \\
\hline & & Median (SE) & Min-Max & Median (SE) & Min.-Max \\
\hline \multicolumn{6}{|l|}{ Academic Year } \\
\hline First-year & $177(30.0)$ & $99.0(1.356)$ & $54.0-155.0$ & $5.50(0.628)$ & $-18.50-34.50$ \\
\hline Second-year & $152(26.0)$ & $93.5(1.620)$ & $46.0-174.0$ & $8.00(0.875)$ & $-11.00-38.00$ \\
\hline Third-year & $126(21.5)$ & $100.0(1.613)$ & $51.0-140.0$ & $5.75(0.796)$ & $-8.00-35.00$ \\
\hline Fourth-year & $132(22.5)$ & $96.0(1.575)$ & $48.0-144.0$ & $6.25(0.877)$ & $-11.50-35.50$ \\
\hline Test & & \multicolumn{2}{|c|}{$\mathrm{p}=.005 / \mathrm{KW}: 12.753$} & \multicolumn{2}{|c|}{$\mathrm{p}=.306 / \mathrm{KW}: 3.617$} \\
\hline \multicolumn{6}{|l|}{ Gender } \\
\hline Female & $358(61.0)$ & $94.0(1.009$ & $46.0-174.0$ & $7.00(0.496)$ & $-18.50-36.00$ \\
\hline Male & $229(39.0)$ & $100.0(1.196$ & $49.0-131.0$ & $4.00(0.643)$ & $-11.00-38.00$ \\
\hline Test & & \multicolumn{2}{|c|}{$p=.029 / Z:-2.180$} & \multicolumn{2}{|c|}{$\mathrm{p}=.008 / Z:-2.658$} \\
\hline \multicolumn{6}{|l|}{ High School Graduate } \\
\hline $\begin{array}{l}\text { Vocational School of } \\
\text { Health }\end{array}$ & $23(3.9)$ & $97.0(4.449)$ & $51.0-155.0$ & $7.50(2.164)$ & $-9.00-29.00$ \\
\hline Anatolian High School & $349(59.5)$ & $96.0(0.987)$ & $46.0-174.0$ & $6.00(0.512)$ & $-11.50-38.00$ \\
\hline Science High School & $6(1.0)$ & $103.5(7.050)$ & $71.0-122.0$ & $16.00(3.330)$ & $4.00-26.50$ \\
\hline General High School & $140(23.9)$ & $98.0(1.611)$ & $51.0-144.0$ & $6.00(0.819)$ & $-18.50-35.50$ \\
\hline Associate Degree & $22(3.7)$ & $90.5(3.926)$ & $51.0-120.0$ & $3.75(2.064)$ & $-4.50-33.50$ \\
\hline Other & $47(8.0)$ & $96.0(2.787)$ & $48.0-126.0$ & $7.50(0.329)$ & $-4.00-32.50$ \\
\hline Test & & \multicolumn{2}{|c|}{$\mathrm{p}=.599 / \mathrm{KW}: 3.661$} & \multicolumn{2}{|c|}{$\mathrm{p}=.319 / \mathrm{KW}: 5.867$} \\
\hline \multicolumn{6}{|c|}{ Owning a Personal Computer } \\
\hline Yes & $136(23.2)$ & $96.0(1.699)$ & $48.0-144.0$ & $8.50(0.873)$ & $-7.00-35.50$ \\
\hline No & $451(76.8)$ & $97.0(0.866)$ & $46.0-174.0$ & $6.00(0.437)$ & $-18.50-38.00$ \\
\hline Test & & \multicolumn{2}{|c|}{$\mathrm{p}=.638 / \mathrm{Z}:-0.470$} & \multicolumn{2}{|c|}{$\mathrm{p}=.002 / \mathrm{Z}:-3.137$} \\
\hline \multicolumn{6}{|c|}{ Education / Course Taking Status About Computer Usage } \\
\hline Yes & $57(9.7)$ & $99.0(2.316)$ & $51.0-121.0$ & $7.00(1.396)$ & $-4.50-35.50$ \\
\hline No & $530(90.3)$ & $96.0(0.820)$ & $46.0-174.0$ & $6.00(0.411)$ & $-18.50-38.00$ \\
\hline Test & & \multicolumn{2}{|c|}{$\mathrm{p}=.754 / \mathrm{Z}:-0.313$} & \multicolumn{2}{|c|}{$\mathrm{p}=.275 / \mathrm{Z}:-1.092$} \\
\hline \multicolumn{6}{|c|}{ View the Effect of Computer Use on Patient Care } \\
\hline Positive View & $525(89.4)$ & $96.0(0.824)$ & $46.0-174.0$ & $6.50(0.424)$ & $-18.50-38.00$ \\
\hline Negative View & $62(10.6)$ & $102.0(2.187)$ & $49.0-124.0$ & $3.75(1.016)$ & $-5.50-34.00$ \\
\hline Test & & \multicolumn{2}{|c|}{$\mathrm{p}=.061 / \mathrm{Z}:-1.872$} & \multicolumn{2}{|c|}{$p=.025 / Z:-2.248$} \\
\hline \multicolumn{2}{|c|}{ Age of Students (mean \pm SD) } & \multicolumn{4}{|c|}{$20.66 \pm 1.79$ (min: 18; max: 32) } \\
\hline \multicolumn{6}{|l|}{$\begin{array}{l}\text { SE: Standard Error } \\
\text { KW: Kruskal-Wallis H } \\
\text { Z: Mann-Whitney U } \\
\text { SD: Standard Deviation } \\
\text { *p }<0.05\end{array}$} \\
\hline
\end{tabular}


Table 3 shows the participants' mean PATCH subgroup scores. Students had a mean PATCH score 8.36 \pm 9.58 . None of the participants fell into group one (fear of technology), $0.2 \%$ were in group two (uncomfortable using computers), $4.6 \%$ were in group three (moderately comfortable using computers), $64.7 \%$ were in group four (comfortable using computers), $24.7 \%$ were in group five (sure of abilities to use various computer programs), and $5.8 \%$ were in group six (very confident in learning how to use computers to increase creativity and health care operability).

The PSI was weakly and negatively correlated with the PATCH $(p<0.000, r=-0.363)$.
Table 4 shows the distribution of participants' PSI and PATCH scores based on some independent variables. Nursing students who love the nursing profession and choose the nursing profession to help people had significantly lower PSI scores and significantly higher PATCH scores $(p<0.05)$. Table 5 shows the distribution of nursing students' PSI and PATCH scores according to preferred activities on the computer. The PSI scores of the nursing students who said yes to accessing information sources / browsing topics, to follow information / news / current sources on the internet and preparing homework were found to be significantly lower and their PATCH scores were significantly higher $(p<0.05)$.

\begin{tabular}{|l|c|c|}
\hline \multicolumn{1}{|c|}{ Table 2. Nursing Students' PSI Subscale Score Means $(n=587)$} & X \pm SD & Min.- Max. \\
\hline Hasty Approach & $30.74 \pm 7.04$ & $9.00-52.00$ \\
\hline Self-Confident Approach & $17.23 \pm 5.50$ & $6.00-34.00$ \\
\hline Thinking Approach & $14.08 \pm 4.63$ & $5.00-29.00$ \\
\hline Avoidant Approach & $11.52 \pm 4.80$ & $4.00-24.00$ \\
\hline Planned Approach & $11.30 \pm 3.79$ & $4.00-24.00$ \\
\hline Evaluative Approach & $8.52 \pm 3.25$ & $3.00-18.00$ \\
\hline PSI Total Score Mean & $93.41 \pm 18.73$ & $46.00-174.00$ \\
\hline $\begin{array}{l}\text { X: Mean } \\
\text { SD: Standard Deviation }\end{array}$ & & \\
\hline
\end{tabular}

\begin{tabular}{|c|c|c|c|c|c|c|c|c|}
\hline Subgroups & $\begin{array}{l}\text { Score Range } \\
\text { Available }\end{array}$ & n (\%) & Min. & Max. & $\mathrm{X} \pm \mathrm{SD}$ & Median & SE & Test \\
\hline Group 1 & -40 to -28 & $0(0)$ & 0 & 0 & 0 & 0 & 0 & \multirow{6}{*}{$\begin{array}{c}p<.001 \\
K W: 416.646\end{array}$} \\
\hline Group 2 & -27 to -15 & $1(0.2)$ & -18.50 & -18.50 & 0 & -18.50 & 0 & \\
\hline Group 3 & -14 to -4 & $27(4.6)$ & -11.50 & -4.00 & $-5.66 \pm 2.27$ & -4.50 & 0.437 & \\
\hline Group 4 & -3 to 12 & $380(64.7)$ & -3.50 & 12.00 & $3.76 \pm 4.13$ & 3.00 & 0.212 & \\
\hline Group 5 & 13 to 26 & $145(24.7)$ & 12.50 & 26.00 & $17.81 \pm 3.56$ & 18.00 & 0.296 & \\
\hline Group 6 & 27 to 40 & $34(5.8)$ & 26.50 & 38.00 & $31.39 \pm 3.28$ & 31.25 & 0.563 & \\
\hline Total & -40 to 40 & $587(100.0)$ & -18.50 & 38.00 & $8.36 \pm 9.58$ & 6.50 & 0.395 & \\
\hline \multicolumn{9}{|c|}{$\begin{array}{l}\text { X: Mean } \\
\text { SD: Standard Deviation } \\
\text { SE: Standard Error } \\
\text { KW: Kruskal-Wallis H }\end{array}$} \\
\hline
\end{tabular}


Table 4. Distribution of Nursing Students' PSI and PATCH Scores According to Some Independent Variables (n:587)

\begin{tabular}{|c|c|c|c|c|c|}
\hline \multirow{2}{*}{ Variables } & \multirow{2}{*}{ n (\%) } & \multicolumn{2}{|c|}{ PSI } & \multicolumn{2}{|c|}{ PATCH } \\
\hline & & Median (SE) & Min-Max & Median (SE) & Min.-Max \\
\hline \multicolumn{6}{|c|}{ Perceived Barriers in the Learning Process } \\
\hline \multicolumn{6}{|l|}{ Economic issues } \\
\hline Yes & $284(48.4)$ & $97.0(1.073)$ & $48.0-140.0$ & $5.00(0.547)$ & $-18.50-38.00$ \\
\hline No & $303(51.6)$ & $96.0(1.111)$ & $46.0-174.0$ & $7.50(0.566)$ & $-11.00-36.00$ \\
\hline Test & & \multicolumn{2}{|c|}{$\mathrm{p}=.464 / \mathrm{Z}:-0.732$} & \multicolumn{2}{|c|}{$p=.044 / Z:-2.017$} \\
\hline \multicolumn{6}{|l|}{ Time issues } \\
\hline Yes & $307(52.3)$ & $94.0(1.051)$ & $48.0-140.0$ & $6.50(0.547)$ & $-18.50-35.00$ \\
\hline No & $280(47.7)$ & $100.0(1.108)$ & $46.0-174.0$ & $5.25(0.573)$ & $-10.00-38.00$ \\
\hline Test & & \multicolumn{2}{|c|}{$p=.000 / Z:-4.094$} & \multicolumn{2}{|c|}{$\mathrm{p}=.305 / \mathrm{Z}:-1.026$} \\
\hline \multicolumn{6}{|l|}{ Technology issues } \\
\hline Yes & $161(27.4)$ & $94.0(1.495)$ & $46.0-174.0$ & $7.00(0.773)$ & $-11.50-36.00$ \\
\hline No & $426(72.6)$ & $97.0(0.904)$ & $48.0-155.0$ & $6.00(0.459)$ & $-18.50-38.00$ \\
\hline Test & & \multicolumn{2}{|c|}{$\mathrm{p}=.622 / \mathrm{Z}:-0.493$} & \multicolumn{2}{|c|}{$\mathrm{p}=.087 / \mathrm{Z}:-1.712$} \\
\hline \multicolumn{6}{|l|}{ Research issues } \\
\hline Yes & $98(16.7)$ & $94.0(1.856)$ & $50.0-140.0$ & $8.75(0.862)$ & $-4.00-35.00$ \\
\hline No & $489(83.3)$ & $97.0(0.850)$ & $46.0-174.0$ & $5.50(0.441)$ & $-18.50-38.00$ \\
\hline Test & & \multicolumn{2}{|c|}{$\mathrm{p}=.409 / \mathrm{Z}:-0.825$} & \multicolumn{2}{|c|}{$p=.016 / Z:-2.417$} \\
\hline \multicolumn{6}{|c|}{ Not knowing how to learn } \\
\hline Yes & $149(25.4)$ & $96.0(1.506)$ & $56.0-144.0$ & $8.50(0.705)$ & $-9.00-35.00$ \\
\hline No & $438(74.6)$ & $96.5(0.901)$ & $46.0-174.0$ & $5.25(0.471)$ & $-18.50-38.00$ \\
\hline Test & & \multicolumn{2}{|c|}{$\mathrm{p}=.746 / Z:-0.324$} & \multicolumn{2}{|c|}{$p=.008 / Z:-2.669$} \\
\hline \multicolumn{6}{|c|}{ Reasons for Choosing the Profession* } \\
\hline \multicolumn{6}{|c|}{ More job opportunities } \\
\hline Yes & $353(60.1)$ & $96.0(0.983)$ & $46.0-174.0$ & $7.00(0.499)$ & $-18.50-38.00$ \\
\hline No & $234(39.9)$ & $97.5(1.253)$ & $48.0-140.0$ & $4.75(0.646)$ & $-11.50-35.50$ \\
\hline Test & & \multicolumn{2}{|c|}{$\mathrm{p}=.497 / Z:-0.679$} & \multicolumn{2}{|c|}{$\mathrm{p}=.054 / \mathrm{Z}:-1.924$} \\
\hline \multicolumn{6}{|l|}{ Helping people } \\
\hline Yes & $142(24.2)$ & $93.0(1.678)$ & $51.0-174.0$ & $9.50(0.781)$ & $-11.50-35.00$ \\
\hline No & $445(75.8)$ & $98.0(0.865)$ & $46.0-144.0$ & $5.00(0.453)$ & $-18.50-38.00$ \\
\hline Test & & \multicolumn{2}{|c|}{$p=.009 / Z:-2.597$} & \multicolumn{2}{|c|}{$p=.000 / Z:-3.819$} \\
\hline \multicolumn{6}{|l|}{ Like profession } \\
\hline Yes & $138(23.5)$ & $94.5(1.526)$ & $49.0-155.0$ & $8.50(0.748)$ & $-11.50-34.00$ \\
\hline No & $449(76.5)$ & $98.0(0.894)$ & $46.0-174.0$ & $5.00(0.461)$ & $-18.50-38.00$ \\
\hline Test & & $p=$. & & $p=$. & 071 \\
\hline $\begin{array}{l}\text { SE: Standard Error } \\
\text { Z: Mann-Whitney U } \\
{ }^{*} \mathrm{p}<0.05\end{array}$ & & & & & \\
\hline
\end{tabular}


Table 5. Distribution of Nursing Students' PSI and PATCH Scores According to Preferred Activities on the Computer (n:587)

\begin{tabular}{|c|c|c|c|c|c|}
\hline \multirow{2}{*}{$\begin{array}{l}\text { Preferred Activities } \\
\text { on the Computer }\end{array}$} & \multirow{2}{*}{ n (\%) } & \multicolumn{2}{|c|}{ PSI } & \multicolumn{2}{|c|}{ PATCH } \\
\hline & & Median (SE) & Min-Max & Median (SE) & Min-Max \\
\hline \multicolumn{6}{|c|}{ Accessing information sources / browsing topics } \\
\hline Yes & $242(41.2)$ & $92.0(1.323)$ & $46.0-174.0$ & $8.50(0.597)$ & $-11.50-38.00$ \\
\hline No & $345(58.8)$ & $100.0(0.904)$ & $49.0-144.0$ & $4.50(0.520)$ & $-18.50-35.50$ \\
\hline Test & & \multicolumn{2}{|c|}{$p=.000 / Z:-4.339$} & \multicolumn{2}{|c|}{$p=.000 / Z:-3.807$} \\
\hline \multicolumn{6}{|c|}{ To follow information / news / current sources on the internet } \\
\hline Yes & $290(49.4)$ & $93.0(1.154)$ & $46.0-174.0$ & $7.50(0.564)$ & $-11.00-38.00$ \\
\hline No & $297(50.6)$ & $100.0(0.998)$ & $49.0-144.0$ & $4.50(0.552)$ & $-18.50-35.50$ \\
\hline Test & & \multicolumn{2}{|c|}{$p=.000 / Z:-4.531$} & \multicolumn{2}{|c|}{$p=.035 / Z:-2.106$} \\
\hline \multicolumn{6}{|l|}{ Using e-mail } \\
\hline Yes & $91(15.5)$ & $88.0(2.250)$ & $46.0-174.0$ & $9.50(1.180)$ & $-7.00-38.00$ \\
\hline No & $496(84.5)$ & $97.0(0.811)$ & $48.0-155.0$ & $6.00(0.411)$ & $-18.50-35.50$ \\
\hline Test & & \multicolumn{2}{|c|}{$\mathrm{p}=.004 / Z:-2.865$} & \multicolumn{2}{|c|}{$p=.010 / Z:-2.559$} \\
\hline \multicolumn{6}{|c|}{ Chat / WhatsApp / Communication with friends } \\
\hline Yes & $331(56.4)$ & $95.0(1.080)$ & $46.0-174.0$ & $7.00(0.546)$ & $-18.50-36.00$ \\
\hline No & $256(43.6)$ & $98.0(1.089)$ & $49.0-144.0$ & $5.00(0.566)$ & $-11.00-34.00$ \\
\hline Test & & \multicolumn{2}{|c|}{$p=.101 / Z:-1.639$} & \multicolumn{2}{|c|}{$\mathrm{p}=.082 / \mathrm{Z}:-1.741$} \\
\hline \multicolumn{6}{|c|}{ Using social media (facebook, instagram ects.) } \\
\hline Yes & $284(48.4)$ & $94.5(1.153)$ & $48.0-174.0$ & $7.50(0.594)$ & $-18.50-36.00$ \\
\hline No & $303(51.6)$ & $100.0(1.028)$ & $46.0-144.0$ & $4,50(0.518)$ & $-10.00-38.00$ \\
\hline Test & & \multicolumn{2}{|c|}{$p=.007 / Z:-2.709 v$} & \multicolumn{2}{|c|}{$p=.001 / Z:-3.273$} \\
\hline \multicolumn{6}{|l|}{ Preparing homework } \\
\hline Yes & $236(40.2)$ & $94.0(1.229)$ & $48.0-174.0$ & $8.50(0.613)$ & $-18.50-38.00$ \\
\hline No & $351(59.8)$ & $99.0(0.983)$ & $46.0-155.0$ & $5.00(0.513)$ & $-11.50-36.00$ \\
\hline Test & & \multicolumn{2}{|c|}{$p=.001 / Z:-3.336$} & \multicolumn{2}{|c|}{$\mathrm{p}=.002 / \mathrm{Z}:-3.143$} \\
\hline \multicolumn{6}{|l|}{ Surf on Internet } \\
\hline Yes & $260(44.3)$ & $95.5(1.196)$ & $46.0-174.0$ & $7.50(0.639)$ & $-11.50-38.00$ \\
\hline No & $327(55.7)$ & $97.0(1.012)$ & $51.0-143.0$ & $5.00(0.489)$ & $-18.50-35.00$ \\
\hline Test & & \multicolumn{2}{|c|}{$\mathrm{p}=.392 / \mathrm{Z}:-0.856$} & \multicolumn{2}{|c|}{$p=.008 / Z:-2.639$} \\
\hline $\begin{array}{l}\text { SE: Standard Error } \\
\text { Z: Mann-Whitney U } \\
{ }^{*} p<0.05\end{array}$ & & & & & \\
\hline
\end{tabular}

\section{Discussion}

This study aimed to determine the relation between nursing students' problem-solving skills and attitudes toward computer use in health care.

This result shows that the nursing students participating in the study were at a moderate level in problem-solving skills (Table 2). According to this result, it can be said that the problem solving skills of nursing students need to be developed. There are many studies in the literature with different results where nursing students are examined on problem-solving skills $(7,9,10,11,23,24)$. The results of some of these studies are in line with the results of this study. Ilıman (2017), Yüksel (2015), and Koç et al. (2015) reported nursing students' mean PSI total scores indicating moderate problem-solving skills, which is similar to this study's result. Nurses should possess problem-solving skills to be able to provide professional, safe, and individual-oriented care (25). For this reason, it is important that nursing students gain problem-solving skills during their education. It can be said that interactive methods should be used in the education process and critical thinking skills should be developed in the development of problem solving skills. 
It is thought that individuals with effective problem-solving skills can cope with the negative emotions and situations that arise, and they can turn negative situations into advantageous opportunities for individual growth. In addition, the literature shows that students with strong problem-solving skills have low social anxiety and high social resilience (6), and students with weak problem-solving skills showed an increase in suicidal thoughts (26). Whatever the reason may be for a lack in problem-solving skills, university counseling and psychological services can guide students to develop the problem-solving skills necessary to thrive in their personal, social, and professional/academic lives.

As a result of the literature review, the PSI total score is as in the study, considering the subdimensions of some moderately evaluated studies (10, 23, 27). Ilıman (2017) reported nursing students' mean PSI subscale scores for "planned approach" and "self-confident approach" as $10.61 \pm 3.81$ and $19.31 \pm 5.94$, respectively. Yalçın et al. (2010) reported nursing students' mean PSI subscale scores for "evaluative approach" and "avoidant approach" as $6.96 \pm 2.17$ and $9.06 \pm 3.85$, respectively. Yıldırım et al. (2014) reported nursing students' mean PSI subscale scores for "hasty approach" and "thinking approach" as 30.42 \pm 6.59 and $14.54 \pm 4.39$, respectively. The difference in these results might be due to the fact that those studies were carried out in different provinces; their participants had different sociodemographic characteristics, and different learning models were employed. The subdimension of the "evaluative approach" in this study can be considered as an indication that, prior to the study, the nursing students had had the skills to be able to make decisions and to evaluate the results of their attempts. For the nursing profession, determining the nursing care to be administered to both patients and healthy individuals as well as evaluating the outcomes of these decisions is considered important. In nursing care it is also important to identify patient needs, plan and implement the correct nursing interventions, and evaluate care outcomes.

Considering the minimum and maximum scores that can be obtained from the PATCH, the total mean score of the PATCH shows that nursing students participating in the study were at a moderate level attitudes toward computer use in health care (Table 3). From the studies in the literature carried out on nursing students and nurses by using PATCH, Özen et al. (2017), Oksay Şahin, Yalçın Nar, Pehlivanoğlu Yütmez \& Yılmaz Çam (2016), and Gürdaş Topkaya (2013) reported nursing students' mean PATCH scores $(20,28,29)$ indicating above moderate attitudes toward computer use in health care, which is higher than this study's result. The reasons for the difference between scores from this study and the aforementioned studies are thought to be students' sociodemographic differences, students' level of interaction with the computers in the clinical area of the schools where the studies were conducted, and whether or not students had taken computer-based lessons.

Most of the nursing students in this study were in the fourth and fifth groups of the PATCH, which is similar to the results of previous studies $(18,20,28)$. Atay et al. (2014) reported that $41.7 \%$ and $45.3 \%$ were in groups four and five, respectively. Oksay Şahin et al. (2016) reported that $42.8 \%$ and $44.6 \%$ of nursing students were in the groups four and five, respectively. Özen et al. (2017) reported that $52.9 \%$ and $37.1 \%$ of nursing students were in the groups four and five, respectively. Advances in technology impose new roles on nurses. Nurses' readiness for information and communication technology plays a key role in developing a common terminology and utilizing nursing information systems (30). In this context, it is very important to improve the attitudes of nursing students who will move forward in their professional lives with advancing technology. Research conducted by Abraham and Abdeldafie (2017) concluded that nursing students showed positive attitudes toward computers, and those who showed positive attitude approved of using computers as learning tools (31). Fidancıoğlu, Beydağ, Gök Özer \& Kızılkaya (2008) reported that most nursing students (93.5\%) thought that they should use computers and the internet to be able to carry out their professional responsibilities diligently and in accordance with technical and professional standards (32). None of our participants fell in the first PATCH group, indicating that they do not suffer from cyberphobia nor have anxiety related to computer use in health care. The results also show that more than half of the participants are comfortable using computers (group three) and are aware of the usefulness of computers in health care (group four). Few participants were enthusiastic about or had positive attitudes toward the potential of computer use in health care, suggesting that nursing students should be offered more computer courses and provided with learning activities using computers.

The participants' PSI scores were weakly and negatively correlated with their PATCH scores. The lower the PSI scores, the higher the PATCH scores, indicating that the better the problem-solving skills, the more positive the participants' attitudes toward computer use in health care. This is the first study to investigate both the nursing students' 
problem-solving skills and their attitudes toward computer use in health care. Therefore, this finding has been discussed with the results of other studies related to the subject, and the sample group of these studies is different from this study. Çalışan (2016) reported no correlation between preservice teachers' problem-solving skills and their perceived computer efficacy (33). Yılmaz and Aktürk (2017) reported that the higher the confidence in computer programming, the more positive the students' attitudes toward problem-solving (34). Computers are an integral part of our daily life. They not only make it easier for us to access information, but also guide us in using the information correctly. People actively use computers to solve problems they face in both their personal and professional lives. The results of this study show that nursing students with stronger problem-solving skills are more likely to use computers to solve problems or to access information in health care. In light of this information, it is important for nursing students to develop problem-solving skills because they will likely interact more with computers and highly advanced technological equipment in their future professional lives.

\section{Study Limitations}

The findings obtained from the research can be generalized to students studying in the nursing department of the faculty of health sciences during the 2018-2019 fall semester. Therefore, the results cannot be generalized to the entire population.

\section{Conclusion}

This study result shows that the nursing students participating in the study were at a moderate level in problemsolving skills and were at a moderate level attitudes toward computer use in health care. This study found that nursing students who had low scores on the problemsolving inventory, that is, stronger problem-solving skills, demonstrated more positive attitudes toward computer use in health care.

\section{Recommendations}

Nursing curricula should include courses to help students develop critical thinking and problem-solving skills. Students' problem-solving skills should be evaluated at the beginning of each academic year. Seminars and trainings should be organized on regular basis to raise students' awareness of the advantages and disadvantages of technology and the internet. During clinical internships, mentor nurses should introduce students to nursing informatics.

\section{Acknowledgments}

We would like to thank all of the participating nursing students for taking the time to complete the questionnaires and making this study possible.

\section{References}

1. Jones, J. H. (2005). Evaluation of critical thinking skills in an associate degree nursing program. [Doctor of Education] University of Georgia. Retrieved from: https://getd.libs.uga.edu/pdfs/jones_ jackie_h_200508_edd.pdf

2. Kim, K. S. \& Choi, J. H. (2014). The relationship between problem solving ability, professional self concept and critical thinking disposition of nursing students. International Journal of Bio-Science and Bio-Technology, 6(5), 131-142. https://doi.org/10.14257/ ijbsbt.2014.6.5.13

3. Kim, H. R., Song, Y., Lindquist, R. \& Kang, H. Y. (2015). Effects of team-based learning on problem-solving, knowledge and clinical performance of Korean nursing students. Nurse Education Today, 38, 115-118. https://doi.org/10.1016/j.nedt.2015.12.003

4. Burns, H. K., O'Donnell, J. \& Artman, J. (2010). High-fidelity simulation in teaching problem solving to 1 st-year nursing students: A novel use of the nursing process. Clinical Simulation in Nursing, 6, 87-95. https://doi.org/10.1016/j.ecns.2009.07.005

5. Yüksel, A. \& Öz, F. (2018). Hemşirelik öğrencilerinin üniversiteye uyumunda problem çözmeye dayalı psikoeğitim programının etkinliğinin değerlendirilmesi. Journal of International Lingual, Social and Educational Sciences, 4(2), 242-262. Retrieved from: http://static.dergipark.org.tr/article-download/7269/ f112/3824/5c2cb0de35332.pdf?

6. Jun, W. H. \& Lee, G. (2017). The role of ego-resiliency in the relationship between social anxiety and problem solving ability among South Korean nursing students. Nurse Education Today, 49, 17-21. https://doi.org/10.1016/j.nedt.2016.11.006

7. Kim, M. J., Ko, G. Y., Park, S. J., Choi, E. Y. \& Park, B. S. (2017). Effects of integrated simulation program on the critical thinking disposition, problem-solving process and job performance of nursing college students. Journal Biomedical Imag Bioeng, 1(2), 47-52. Retrieved from: https://www.alliedacademies.org/articles/ effects-of-integrated-simulation-program-on-the-critical-thinkingdisposition-problemsolving-process-and-job-performance-ofnursin.pdf

8. Bruce, J. C., Lack, M., Bomvana, N. M. \& Qamata-Mtshali, N. (2018) Problem-based learning: Nursing students' attitude, self-reported competence, tutorial performance and self-directed learning readiness. Journal of Nursing Education and Practice, 8(10), 11-19. https://doi.org/10.5430/jnep.v8n10p11

9. Zhang, X.H., Meng, L. N., Liu, H. H., Luo, R.Z., Zhang, C. M., Zhang, P.P.et al. (2018). Role of academic self-efficacy in the relationship between self-directed learning readiness and problem-solving ability among nursing students. Frontiers of Nursing, 5(1), 75-81. Retrieved from: https://www.researchgate.net/publication/324479803

10. Ilıman, A. Y. (2017). Klasik ve entegre eğitim modeli ile öğrenim gören hemşirelik öğrencilerinde problem çözme becerisi ve yaşam boyu öğrenme eğilimi. [master thesis] University of Marmara. Retrieved from: https://tez.yok.gov.tr/UlusalTezMerkezi/

11. Koç, Z., Koyuncu, S. \& Sağlam, Z., (2015). Sağlık yüksekokulu hemşirelik ve ebelik öğrencilerinin problem çözme beceri düzeyleri ve etkileyen faktörler. Hemşirelikte Eğitim ve Araştırma Dergisi, 12(1), 41-50. https://doi.org/10.5222/HEAD.2015.041

12. Mertoğlu, H. \& Öztuna, A. (2004). Bireylerin teknoloji kullanımı problem çözme yetenekleri ile ilişkili midir? The Turkish Online Journal of Educational Technology, 3(1), Article 12. Retrieved from: http://www.tojet.net/articles/v3i1/3112.pdf 
13. Bilgiç, Ş.\&Şendir,M. (2014). Hemşirelikbilişimi.CumhuriyetHemşirelik Dergisi, 3(1), 24-28. Retrieved from: https://www.researchgate. net/profile/Merdiye_Sendir/publication/264120844_Hemsirelik_ Bilisimi-Nursing_Informatics/links/53ceca560cf25dc05cfaceab.pdf

14. Gonen, A. \& Lev-Ari L. (2016). The impact of sociological factors on nurse educators' use of information technology. Journal of Health Education Research \& Development, 4(4), 1-7. https://doi. org/10.4172/2380-5439.1000205

15. Kihnula, N. (2017). Learning clinical competence with mobile technology in nursing education: A literature review. [Nursing AMK, Thesis] Helsinki Metropolia University of Applied Sciences. Retrieved from: https://www.theseus.fi/bitstream/handle/10024/136140/ Kihnula_Noora_Thesis.pdf?sequence $=1$

16. Skiba, D. J., Connors, H. R. \& Jeffries, P. R. (2008). Information technologies and the transformation of nursing education. Nursing Outlook, 56, 225-230. https://doi.org/10.1016/j.outlook.2008.06.012

17. Şenyuva, E. (2019). Teknolojik gelişmelerin hemşirelik eğitimine yansımaları. Florence Nightingale Journal of Nursing, 27(1), 79-90. Retrieved from: https://cdn.istanbul.edu.tr/file/1CD58DF90A/42A82 04D5A5E4FB8974BB3D9B6D15241?doi=10.26650/FNJN322556

18. Atay, S., Arıkan, D., Fatma, Y., Aslantürk, N. \& Uzun, A. (2014). Nursing and midwifery students' attitudes to computer use in healthcare. Nursing Practice Today, 1(3), 147-154. Retrieved from: http://npt. tums.ac.ir/index.php/npt/article/view/22

19. Vijayalakshmi, P., Ramachandra. \& Math, S. B. (2014). Nursing students' attitudes towards computers in health care: A comparative analysis. Journal Health Inform, 6(2), 46-52. Retrieved from: https:// nursing-informatics.com/niassess/286-1283-1-PB.pdf

20. Özen, N., Yazıcıoğlu, İ. \& Çınar, F. İ. (2017). Hemşirelik öğrencilerinin sağlık bakımında bilgisayar kullanımına yönelik tutumları ile klinik karar verme becerileri arasındaki ilișkinin incelenmesi. Hemşirelikte Eğitim ve Araştırma Dergisi, 4(2), 112-118. https://doi.org/10.5222/ HEAD.2017.112

21. Şahin, N., Şahin, N. H. \& Heppner, P.P. (1993). Psychometric properties of the Problem Solving Inventory in a group of Turkish university students. Cognitive Therapy and Research, 17(4), 379-396. Retrieved from: https://link.springer.com/content/pdf/10.1007/BF01177661. pdf

22. Kaya, N. \& Aşti, T. (2008). Sağlık bakımında bilgisayar kullanımına yönelik tutum ölçeğinin güvenirlik ve geçerliği. İstanbul Üniversitesi Florence Nightingale Hemşirelik Dergisi, 16(61), 24-32. Retrieved from: https://toad.halileksi.net/sites/default/files/pdf/saglikbakiminda-bilgisayar-kullanimina-yonelik-tutum-olcegi-toad.pdf

23. Yıldııım, B., Özkahraman Koç, ş. \& Sarıkaya Karabudak, S. (2014). Hemşirelik ve ebelik öğrencilerinin problem çözme becerileri ile öğrenme biçimleri arasındaki ilişkinin incelenmesi. Gümüşhane Üniversitesi Sağlık Bilimleri Dergisi, 3(3), 859 - 882. Retrieved from: https://pdfs.semanticscholar.org/d523/9a8366a6b00b2ef8c7772bd 97291102a4756.pdf

24. Yüksel, A. (2015). Hemşirelik öğrencilerinin problem çözme öz değerlendirme sonuçları ve etkileyen faktörler araştırması. Hacettepe Üniversitesi Hemşirelik Fakültesi Dergisi, 2(1), 37-49. Retrieved from: http://www.hacettepehemsirelikdergisi.org/pdf/ pdf_HHD_180.pdf

25. Tercanlı, N. (2011). Hemşirelerin algıladıkları sosyal destek ile problem çözme becerisi arasındaki ilişki. [master thesis] University of Atatürk. Retrieved from: https://tez.yok.gov.tr/UlusalTezMerkezi/

26. Abdollahi, A., Hosseinian, S., Zamanshoar, E., Beh-Pajooh, A. \& Carlbring, P. (2018) The moderating effect of hardiness on the relationships between problem-solving skills and perceived stress with suicidal ideation in nursing students. Studia Psychologica, 60(1), 30-41. https://doi.org/10.21909/sp.2018.01.750
27. Yalçın, B., Tetik, S. \& Açıkgöz, A. (2010). Yüksekokul öğrencilerinin problem çözme becerisi algıları ile kontrol odağı düzeylerinin belirlenmesine yönelik bir araştırma. Organizasyon ve Yönetim Bilimleri Dergisi, 2(2), 19-27. Retrieved from: http://static.dergipark. org.tr/article-download/imported/5000145200/5000132540.pdf?

28. Oksay Şahin, A., Yalçın Nar, M., Pehlivanoğlu Yütmez, T. \& Yılmaz Çam, Ç. (2016). Hemşirelik bölümü öğrencilerinin sağlık bakımında bilgisayar kullanımına yönelik tutumları. Turkiye Klinikleri Journal Surgical Nursing-Special Topics, 2(1), 91-96. Retrieved from: https://www.turkiyeklinikleri.com/article/tr-hemsirelik-bolumuogrencilerinin-saglik-bakiminda-bilgisayar-kullanimina-yoneliktutumlari-75138.htm

29. Gürdaş Topkaya, S. (2013). Hemşirelerin bilgisayar okuryazarlığının sağlık bakımında bilgisayar kullanımına yönelik tutumlarına etkisi. [master thesis] University of Istanbul. Retrieved from: https://tez.yok. gov.tr/UlusalTezMerkezi/

30. Köse, A. (2011). Hemşirelerin bilgisayar kullanım durumları ve hemşirelik bilişimi hakkında düşünceleri: Trabzon iline ait bir çalısma. [master thesis] University of Karadeniz Teknik. Retrieved from: https://tez.yok.gov.tr/UlusalTezMerkezi/

31. Abraham, B. K. \& Abdeldafie, S. Y. (2017) Attitude of nursing students towards computer assisted learning in a selected nursing college, Hafar al Batin, Saudi Arabia. International Journal of Innovative Research in Medical Science, 2(4), 686-691. Retrieved from: https:// scholar.google.com.tr/scholar?cluster $=16292691361629014835 \&$ hl $=e n \& a s \_s d t=0,5 \& a s \_v i s=1$

32. Fidancıoğlu, H., Beydağ, K. D., Gök Özer, F. \& Kızılkaya, M. (2008). Sağlık yüksekokulu öğrencilerinin internet kullanımına yönelik görüşleri. Maltepe Üniversitesi Hemşirelik Bilim ve Sanatı Dergisi, 2(1), 3-8. Retrieved from: https://docplayer.biz.tr/6575768-Saglikyuksekokulu-ogrencilerinin-internet-kullanimina-yonelik-gorusleri. html

33. Çalışkan, E. F. (2016). Öğretmen adaylarının algılanan bilgisayar yeterlilikleri ile problem çözme becerileri arasındaki ilişkinin incelenmesi. 15. Uluslararası Sınıf Öğretmenliği Eğitimi Sempozyumu, Muğla Sıtkı Koçman Üniversitesi. Retrieved from: http://usos2016.com/usos2016-bildiri-ozet-kitabi.pdf

34. Yılmaz, O. \& Aktürk, A. O. (2017). Meslek lisesi öğrencilerinin problem çözme becerileri ile bilgisayar programlamaya karşı tutumlar arasındaki ilişkinin incelenmesi. International Conference on Education in Mathematics, Science \& Technology, 18-21. Retrieved from: https://www.researchgate.net/publication/322196395 